\title{
AN EMPIRICAL STUDY OF ISLAMIC MICROFINANCE PERFORMANCE FOR POOR FAMILY: MAQASHID $A L$ - SHARIA PERSPECTIVE
}

\author{
Aas Nurasyiah ${ }^{1^{*}}$ \\ ${ }^{1}$ Universitas Pendidikan Indonesia, Bandung, Indonesia
}

\begin{abstract}
This research motivated by Islamic Microfinance performance measurement which still adopting on the performance measurement of microfinance in general that limited to the measurement of material. Therefore, efforts urgently needed to introduce more holistic measurement in assessing the performance of Islamic Microfinance based on tawheed principle. Thus, this study aims to measure the performance of Islamic Microfinance institutions based on Maqashid Al-Sharia. This research method uses quantitative approach with descriptive quantitative research design, which measures variables based on certain indicators. The location of the research is KOPMU-DT as one of the Islamic Microfinance institutions located in Bandung. The population of the study was the members KOPMU-DT wide-spread, among thousand people, but the withdrawal sample technique uses non-probability sampling with a sample of 100 members, based on the criteria that have been determined. Based on the research result, generally the members of KOPMU-DT increased living standards of the family economy and the performance of running microbusinesses. In Maqashid Al-Sharia perspective, the members experience a change in the principles of Ad-Din Al-Aql, A-nafs, An-Nasl and Al-Maal. However, among five principles, Al-Aql increases lower than other principles. In the future, to improve the performance of Islamic Microfinance, especially in KOPMU-DT, needs technical effort / business of accompaniment improvement to develop entrepreneurship from members. In addition, needs to give appreciation to the consistent members and disciplined in order to refund to add its financing to stimulate the operating business, without losing spiritual accompaniment to strengthen the achievement of Maqashid Al-Sharia of the empowerment members of Islamic Microfinance institution.
\end{abstract}

Keywords: Islamic Microfinance, Maqashid Al-Sharia, Performance

\section{INTRODUCTION}

Islamic Microfinance has been proven empirically as the hacker of poverty and improved the welfare of the people in general (Mizanur Rahman, 2010; Durrani et.all 2011; Aslaam, 2014). Islamic Microfinance has different characteristics with microfinance. According to Ahmed (2002) conclude some differences among the Islamic Microfinance and microfinance, conventional microfinance based on interest while Islamic Microfinance should eliminate interest and use profit-sharing in its operation. Besides, Islamic Microfinance could utilize the Islamic deed form such as zakat, infaq, shodaqoh and waqaf as the financial source in social service to fulfil the basic needs and improve the

* Corresponding author. Email address: asnur.fna@upi.edu 
participation of poor's. So, in the program development of Islamic Microfinance, make sharia values integrated in the form of conduct, ethics and social. Thus, the main characteristic of the microfinance sharia performance (Islamic Microfinance) is to extent which people can obtain financing to achieve the goals of sharia (maqashid Al-Sharia).

Maqashid Al-Sharia terminologically comes from two syllables, namely maqashid and Sharia. Maqashid is jama form of Maqsud meaning intent or purpose. The Sharia means the path to the water, or path to the source of life. Thus, terminologically maqashid Al-Sharia meaning of Allah as the creator of sharia provide benefit to humans with the fulfilment of the needs dharuriyah, hajjiyah and tahsaniyah in order to obtain a good life and Hereafter (Fauzia, 2016). According to Imam Al-Ghazali that maqashid Al-Sharia is to maintain sharia goals, which: 1. Protection of religion (ad-din); 2. Protection of Life (an$n a f s) ; 3$. Protection of Intellect ( $a l$-'aql); 4. Protection of Descent / Honour (annasl); and 5. Protection of Assets (al-maal).

In its implementation, in Indonesia maqashid Al-Shariah goals attainment is not always illustrated by the performance of Baitul Maal Wat Tamwil (BMT) or sharia cooperative as a manifestation of Islamic Microfinance institutions. Based on the results of the study authors (Nurasyiah, et.all, 2016) in some BMT that the majority of Islamic Microfinance institutions still focus on its business orientation, namely to achieve the target of many members, the achievement of high financing to gain a huge advantage. As for assistance or empowerment of member in economy and social, including spiritual guidance is still rarely performed. Based on the interview results there are some possibilities of this problem, such as the absence of intention of the management of the Islamic Microfinance institution to pay attention of members in terms of Maqashid sharia, so the implementation of program activities are not portrayed leads to Maqashid Sharia overall, or on the other hand Islamic Microfinance institutions find it difficult to collect or request time from members to routinely get assistance in business, technical and spiritual aspects.

According to Choudhury $(2010,2011)$ said that to understand epistemology Tawheed is very substantial in the implementation of Islamic financial institutions, including Islamic Microfinance program for poor's. He said each program should be aimed at achieving the maqasid al-sharia principles. If the conventional microfinance approach adopted by the Islamic Microfinance without the concept of Tawheed, the result is only the rich and those who have gained great importance who can get service from Islamic financial institutions. Among the substances that must exist in the Islamic Microfinance based on the principle of monotheism, that is the maqasid sharia, trust, qard-hasan and cooperative. Fight to against interest; and the process of learning / shuratic process (Abdullah and Ismail, 2014).

Thus, incorporating elements of maqashid Al-Sharia in Islamic Microfinance becomes an important thing, because the purpose of all Islamic financial institutions should be holistic, overarching achievement of welfare, welfare that is both material and spiritual. There must be a balance between the two, because the Islamic view of the economic achievement relating to wealth, in its principle is a test, not becoming rich then abandon the principles of sharia, as happens in programs of conventional microfinance systems, because the focus is only serving on economic aspects and generally performed by housewives. For example, the Grameen Bank program, the economic condition 
of housewives from poor families rose sharply, but became inattentive to the main tasks in the household and tends to be selfish and trigger a high divorce rate. Therefore, Islamic Microfinance model is needed which include compliance based on the perspective of monotheism. During this time Microfinance Islamic studies only focus on financial instruments which should be free of usury, not pay attention to sharia compliance in all aspects of Islamic Microfinance and how the achievement of the members who get financing (Abdullah and Ismail, 2014).

A lot of studies have evaluated the role of Islamic Microfinance program using conventional approaches. However, socio-economic measurements in conventional systems cannot evaluate the performance of Islamic Microfinance which more holistic based on sharia goals. Therefore, this study wants to examine further the role of Islamic Microfinance is based on the achievement of maqashid Al-Sharia. Previous research conducted by Dar (2004), which has justified maqashid Al-Sharia as the basis of a theory that can be used for analysis and measure empirical studies, Alam et.all (2015) who has researched empirically on Islamic Microfinance program Amanah Ikhtiar Malaysia. In this research, the author wants to examine empirically how Islamic Microfinance role to poor families based maqashid Al-Sharia. Research was conducted on one of Islamic Microfinance institutions in Indonesia, namely KOPMU- DT, as Islamic Microfinance institutions that are already running on the empowerment of poor families for almost less than ten years.

\section{LITERATURE STUDY}

\subsection{The Development of Islamic Microfinance in Indonesia}

According to Rahman \& Dean (2013) products of conventional microfinance institutions have had great success in Muslim majority countries, particularly the Grameen bank was initiated by Muhammad Yunus in Bangladesh. Although, according to Karim, Tarazi, \& Reille (2008) conventional microfinance clients around $44 \%$ live in Muslim countries, but conventional microfinance clients do not fulfil the needs of many Muslims because they saw conventional financial product choices which not suitable with the principles in sharia (Komi \& Croson, 2005),

Islamic microfinance is a branch of Islamic finance which foundations are embedded in the Qur'an and Sunnah. Islamic microfinance institutions are present and thrive to deliver services to the people especially the poor to obtain the factors of production sharing system, sale, and lease which emphasize on ethical and moral values in business (Usman \& Tasminn, 2016).

Islamic provisions which prohibit usury, speculation and uncertainty are the issues that distinguish Islamic microfinance with conventional microfinance institutions. It is built on the concept of social justice of Islam which prohibits the exploitation behaviour, but encourage people to actively do good to poor's with the concept of profit-sharing, so that the allocation of resources can be divided efficiently (Rahman \& Dean, 2013),

Applicability of profit-sharing system on Islamic microfinance institutions can lead to the equal distribution of income, control and resource allocation become more efficient. The development of Islamic microfinance institutions has brought a positive influence to the benefit of each other within the community and have created real value on improving the living standards (Morsid, 2014), 
In Indonesia, Mursal (2016), said that the Islamic economic system implemented through Islamic banking institutions and various Sharia MicroFinance Institutions (LKMS). The types of Islamic microfinance institutions are Islamic Financial Service Cooperative (KJKS) or better known as Baitul Mal Wattamwil (BMT). Based on the statistical data of Islamic Banking issued by Financial Services Authority (2018) until 2018, there are 42 Islamic Microfinance Institution to manage the assets of Rp. 116 Billion.

\subsection{The Role of Islamic Microfinance for The Poor}

Microfinance institution is an institution that provides financial services to low-income groups and the poor. The initial focus is on the micro loans are usually short-term working to finance small businesses that are usually operated by low-income people. However, microfinance has grown not only in the form of loans, but also include micro savings, micro-insurance, remittances and other payment all that have a major impact on the lives of the poor (Ali, Abu-Hadi and Ali, 2013),

In Indonesia, the definition of poverty is used by the Central Bureau of Statistics (BPS), which is the measurement of the basic needs. In this approach, poverty is seen as an economic inability to meet the basic needs of food and non-food (clothing, housing, education and health) as measured from the expenditure side. So, based on this approach, the concept of the poverty line (GK) built on two main foundations, namely the food poverty line (FPL) and non-food poverty line (GKBM) (BPS, 2018).

The role of Islamic microfinance in reducing poverty has been proven by the results of research conducted by Rena \& Tesfy (2006), which concluded that microfinance is the solution to poverty alleviation. Their results have shown that there is a fundamental relationship between microfinance and poverty alleviation. It depends on the poor people who have access and control over productive resources in economy, which is one of financial resources. In addition, Knight and Farhad (2008) states that micro finance can directly increase the quality of life and push the poverty alleviation programs. By getting loans they can work and poverty declining so that people can live economically independent.

In line with previous research results, Shastri (2009) reveals that there is no better way than microfinance to fight poverty. As well as Kumar, Bohra \& Johari (2010) which found that microfinance is the only way to overcome poverty in India.

In developing Islamic micro-finance, government intervention in terms of economic growth and development is very important. It shows that access and efficient provision of micro-credit that can enable the poor to facilitate consumption, better manage risks, build assets gradually, develop microbusiness, increase revenue capacity, and improve quality of life (Durrani, Usman Malik, and Ahmad, 2011).

\subsection{Performance of Islamic Microfinance based on Maqashid Sharia}

Islamic Microfinance Institutions (LKMS) must keep the goals (maqashid sharia) in providing finance for the poor and needy. The results of research show that poor communities receive funding for a business is relatively trustworthy person. Costs are low and qardhul hasan loans used to replace high interest rates charged by MFIs conventional. With the consultation process, it 
will help Islamic MFIs to understand the poor micro-entrepreneurs (Abdullah and Ismail, 2014).

Dusuki and Bouheraoua (2011) define Maqasid Al-Sharia as the ultimate goal of Islamic law that serves the interests of all humanity (Maslahah). The rules are designed to protect the interests of human life on earth and life thereafter, also to improve and enhance life. Maqasid Al-Sharia is not only set the Muslims, but also to humanity as a whole to adapt to the modernization of human needs. Al-Sharia principle Maqashid built by a prominent Islamic scholar, Al-Shatibi and Al-Ghazali (Alam, Hassan, \& Said, 2015).

Maqasid Al-Sharia has five basic principles (Dusuki \& Bouheraoua, 2011) those are:

1. Religion (Ad-Din): Every Muslim must worship Allah (swt) and find for truth and justice. This principle must be maintained under all circumstances.

2. Life (al-nafs): Respect for human life must be observed to preserve and protect at all times. Human existence must be upheld, and wellbeing of human should not be violated.

3. Intellect ( $a l-A q l)$ : Behavior / association means right or wrong differentiated through freedom of thought, association, and speech. Sharia encourages the quest for knowledge to ensure the intellectual development of Muslims.

4. Descendants (Al-Nasb): liabilities and legal obligations should be made to respect the human community based on the sanctity of life (as reflected in future generations).

5. Wealth (Al-Mal): Economic justice, especially in terms of creating money and wealth, should be established as an alternative to the previous wage system.

\section{METHOD}

This study design is a descriptive-quantitative, which describes a variable size based on certain indicators. In this study, the achievement maqashid AlShariah measured from family members of Islamic Microfinance program. As for Islamic Microfinance institution for the study site is KOPMU-DT. KOPMUDT as a business cooperative that focus on the economic empowerment of productive community particularly among mothers who have business activities or who is determined to have a business in order to improve the economy of families with a pattern of coaching and mentoring. Therefore, KOPMU-DT is present not only provide assistance with the ease of access to capital to the women who are members of KOPMU-DT.

The population in this study is a member of the program of KOPMU-DT. The member KOPMU-DT registered until the month of July 2018 was 2,023 people, but only 1,745 people who entered as an active member. Members KOPMU-DT is divided into several branches of the region, including a branch of Bandung Raya (Bandung, Bandung regency, and West Bandung regency), South Bandung branch, and the branch of Garut.

The number of samples taken based on sampling techniques of nonprobability sampling, where each member of the population does not have the same opportunity. It is in because of population spread across several regional coverage. The type of sampling is purposive sampling, which means that the sampling based on the research needs with specific goals that have specific information for researchers (Sekaran, 2013). 
Required Criteria sampling or respondents in this study were women as housewives who are members of KOPMU-DT, who get sharia financing, and is active in mentoring programs initiated by KOPMU-DT. Based on this, the researchers will take a sample of 100 respondents representing branch Bandung area. It is based on a suggestion of coordinator mentoring and empowerment KOPMU-DT, arguing that branch Bandung area has the most members in comparison with other regions branch which expected to represent the data required in the study. Moreover, it also based on a limited number of researchers in terms of time, cost, and other things.

The primary data obtained processed by Change Assessment and Scoring Tool (CAST), which consists of five scales, those are "very negative", "negative", "No change", "Positive" and "Very Positive" (Alam, et. all, 2015). CAST method built in the mid-1990s as a technique that focuses on a group / group to describe a person's perception of change. This method adopted from Mikkelsen et.al. (2008) to evaluate the variation, poverty level reduction of implementation program of Swedish Development Assistance. This study analysed achievement data of KOPMU member-DT based on the achievement of five principles on maqashid Al-Sharia.

Data collected through the interview process to empowerment members of KOPMU-DT that regularly gather for once a week. Interviews conducted based on the guidelines of instrument that had been developed by researchers. The required time for the data collection process is approximately two weeks. After the data is collected, the researchers conducted a process of input, processing and analysis the data. Input process and data processing using help from Excel. Based on the results of the analysis, the researchers create a data description of each maqashid-Al Sharia indicators. With data descriptions, researchers are able to make conclusions regarding the achievement of maqashid Al-Sharia of DT KOPMU members.

\section{RESULT AND DISCUSSION}

\subsection{Socio-Economic Status of Respondents}

Based on previous exposure that targeted by KOPMU-DT is to empower mothers, then all members of KOPMU-DT consist of women who are married, whether its status is still in a state already married or a widow who has a business. The general characteristics of respondent section will describe the results of research findings related to respondents in the field, such as age, marital status, dependents number, education level, occupation, and length of participation in Islamic Microfinance institutions KOPMU-DT.

Based on the findings from the field, the dominant age of the respondents from members KOPMU-DT is in the age range 48-54 years (29\%), 41-47 years (26\%) and 34-40 years (16\%). It means that about $71 \%$ were in the age range 34-54 years. This shows that most of the members are in the productive age and have a strong desire to actively participating in the economic activities of the family. That is because in the age range of the average member has schoolchildren dependents, which require relatively high cost. The reasons for members who no longer have a dependent child in school should stay in the program launched by the KOPMU-DT is because they do not want to bother their children to bear family economy, so they choose to look for additional income to fulfil their daily needs. 
The number of family member dependents mostly not much, an average of only 1-2 people (69\%) even many who have no dependents. That's because some members have children who are married or work and earn their own income, so they are not borne by the parents, especially his father or the head of another household.

Most respondents in this study only complete school at elementary level, which is about $55 \%$. At junior high school (SMP) is $24 \%$, senior high-school (SMA / SMK) 20\%, and bachelor (S1) 1\%. Qualification may reflect members' knowledge in designing the orientation of life and the ability of members in developing their business. Field findings indicate that most members of KOPMU-DT just completed his education at primary school level. This reflects that most members of KOPMU-DT had limited formal education background. Based on author interviews with members known that low levels of education of members caused by several things, such as their ancient culture that considers higher education does not really matter, so that after the women graduated from primary school or junior high they immediately ordered to get married at very young age. Limitation of cost also becomes one of the reasons why members do not continue their education to a higher level. In addition, the difficulty of road access to the school buildings, the distance from home to school that weakening member's wishes to continue their education to a higher education level.

Low levels of education lead to lack of member's ability to understand every contract deal offered by existing financial institutions, including from KOPMU-DT. In addition, the cause is still lack of understanding on how to manage finances and grow their businesses. However, it did not discourage the members to be serious and diligent in following the empowerment and mentoring program initiated by KOPMU-DT in order to develop the skills and knowledge to develop their business.

Types of jobs held by members of KOPMU-DT is very diverse, ranging from vending and food products (jackets, bags, bed sheets, cosmetics, accessories, food, vegetable rice cake, children snacks, and many others); business services (laundry, therapists, farm workers, domestic assistants, and other services); to be farmers or just be a housewife who all have the potential for business development in order to improve the welfare of the family. Based on the field findings, there are some differences between the characteristics of jobs in Bandung Raya and South Bandung area. Each area has its business potential of each, the majority of efforts undertaken in the area of Bandung Raya members are either in the form of trade credit grocery goods or shape.

Location effort undertaken by members of the majority to open a shop at home, some are selling at a place of recreation, schools, and sell around, as well as fields or gardens for the farmers. The reason members undergo additional effort is as family income or as a side income to help her husband provide for the family. Another reason is as the major economic purpose to fulfil the needs of family life, this thing is usually because members are no longer have a husband.

Household expenses predominately used for food consumption in a day-school expenses of children and micro-financing instalment. The results are based on the average research consumer spending is less than 1 million are $15 \%$, between 1-2 million is 50\% and the average expenditure of 2-3 million is $35 \%$. This means that the majority of respondents spending to be around 1-2 million. Approximately $12 \%$ respondents earn income other than Islamic Microfinance 
program. Revenues from this poor family come also the government in the form of direct cash assistance (BLT), zakat and waqf institutions or NGOs. Values help around 300-500 thousand / month.

\subsection{Islamic Microfinance Performance}

Islamic Microfinance Performance, in this case, measured based on several indicators, as follows: 1) the length of participation, 2) the amount of financing, 3) Administration financing, and 4) The rate of return. The following will explain the results of research and describe every indicator of Islamic Microfinance. The duration of participating members in KOPMU-DT at least impact on the benefits perceived by members. Most members KOPMU-DT (74\%) have followed a program initiated by the agency has been more than 3-4 years. Only around $26 \%$ of the members who join about 1-2 years as DT KOPMU membership.

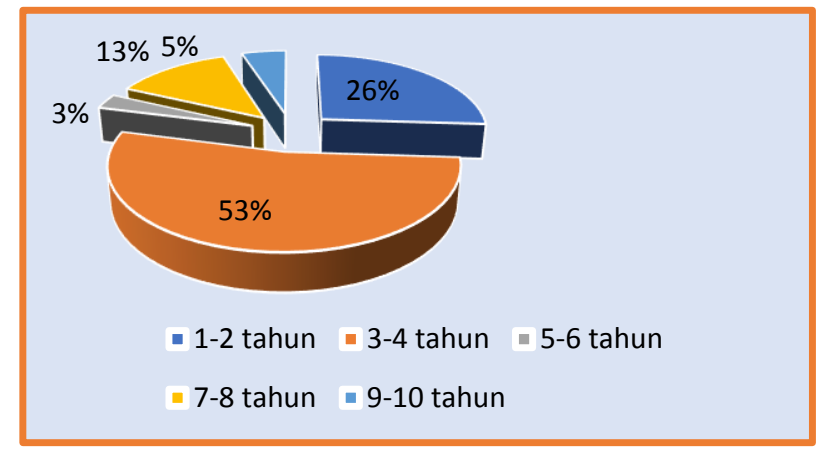

Figure 1 Respondents Based on the Membership Period Source: Summary of Results of research Data Processing

The participation of members in KOPMU-DT institutions mostly have been in a long time, more than three years. The duration of the participating members in KOPMU-DT at least affect the benefits perceived by the members, in both term material as well as spiritual. Most of the perceived benefits of the members in terms of material, such as an increase in the gain of family income, an increase in business turnover, the increase in business assets and assets of households, as well as an increased ability to develop business skills.

In addition, with the mentoring program contains material that is not only business development, but also their moral guidance of the members will have great impact for spiritual life member. The change of the spiritual side member, namely an increase in the quality of worship, including the increasing intensity of charity members through the media such as moneybox in every weekly assembly meeting, it is expected to grow the spirit of generosity to each member. Moreover, the intensity and quality of the Qur'an together with members has increased, along with the delivery of material by the companion foster their increased knowledge of religion for members.

The second indicator used in measuring the performance of Islamic Microfinance is the amount of financing that is measured by how much percentage of the amount of financing provided by KOPMU-DT to members compared to the magnitude of the filing of the financing committed by members of the KOPMU-DT. In addition, the indicator loan amount is also measured by how much of the perceived benefits from financial assistance provided by KOPMU-DT. 
Based on the findings from the field, as many as $67 \%$ of who get financial assistance in accordance with what they propose that approximately $81 \%-100 \%$ of the submission. Funding proposed various kinds, some use murabahah which are commonly used by those members who have a business, especially in the field of trade, some use wakalah are usually submitted by members who will pay school fees for their children, or contract of Ijarah are usually submitted by members who would renovate the house, and many other contracts.

Board-DT branch KOPMU South Bandung area revealed that giving financial assistance that has been done only with the confidence to members of the institution. This is done not without risks, financing problems must be found while in the field. However, by forming a small group that requires its own members selectively entering new members, their joint responsibility in the assembly group into one of the anticipations of financing problems, and the most important is the commitment of the members to be responsible for everything that is done including the obligation to pay.

The third indicator is the administrative problems; it measured by the extent of ease administrative requirements that must fulfil in applying for financing members. Please note financing specified by KOPMU-DT is to use a 2-2-1 pattern, meaning of the five members in one group of eligible first get financing are two of the first, followed by the next two, then the last person the order agreed in advance. 2-2-1 pattern used only on the submission of financing the first stage, the next stage seen from the discipline of members in paying instalments and following the weekly meeting.

Based on author interviews to the members, the majority of members considered that the requirements set by KOPMU-DT in obtaining financing are not difficult to be met by members, members are only required to collect cards (KTP), Family Card (KK), and members were asked to fill several sheets flap on administration of the board that was later discovered by a family member with a clear sign his name in the flap on. Disbursement of financing will be made at the weekly meeting next in the presence of other members as a sign of approval from other members. Therefore, the stages are considered easier for members KOPMU-DT compared to apply for funding to other agencies.

The last indicator, the rate of return is measured by how much it costs member for financing and the extent of the perceived ease of members in paying installments financing. It is important to the author discussed the reason that each different financial institutions in determining the amount of installments shall be members or customers to pay and determine the length of the installment payment term.

Based on field surveys, most of the members of financial institutions expect the amount of installments that are not too big and the period of time is not too fast from the financing process is done. It is felt alleviate the grounds that most of the members work in the informal sector whose income is uncertain each day, week or month, and income was on average not too big so blithely instalments and time-frame of instalment payment can alleviate the members in pay the instalments.

Based on the findings of a field that is based on mutual agreement between the member and KOPMU-DT in the Annual Members Meeting (RAT), set the maximum term of installment payments for 50 weeks. Repayment is done once a week at the time of maximum assistance activities undertaken by the payment of three installments. If there is one member who did not pay at the time of 
counseling, it can be taken from savings installment in question or be borne jointly by all members of the board were present. The conclusion of Islamic Microfinance result description variables can be shown in Table 1.

Table 1 Description of Islamic Microfinance in KOPMU-DT

\begin{tabular}{lcc|}
\hline \multicolumn{1}{c}{ Indicator } & $\begin{array}{c}\text { Indicators } \\
\text { score }\end{array}$ & Category \\
\hline Entanglement with KOPMU-DT & 1,166 & High \\
Total Financing & 827 & Very high \\
Administration & 1,578 & Easy \\
Return & 838 & very Mild \\
\hline \multicolumn{1}{|c|}{ Variable Score $\mathbf{\Sigma}$} & $\mathbf{4 , 4 0 9}$ & Very high \\
\hline
\end{tabular}

Source: Summary of Results and Data Processing

\subsection{The Performance of Micro Business Member in Islamic Microfinance}

Micro business performance of the members of the Islamic Microfinance measured by several indicators, namely: 1) The financial resources, 2) Revenue and 3) creating employment. The measurement of performance refers to the indicators proposed by Alam et.all (2015). To obtain financial capital, mostly small businesses get funding from the government. Therefore, the score is not worth, and then they took the initiative to engage in micro-Islamic financing. The values of the micro financing they receive are as follows:

Table 2 Number of Islamic Microfinance Financing

\begin{tabular}{ccc|}
\hline value Financing & Total & $\begin{array}{c}\text { Percentage } \\
(\boldsymbol{\%})\end{array}$ \\
\hline$<1$ million & 20 & $20 \%$ \\
$1-2$ million & 40 & $40 \%$ \\
$2-3 \quad$ Million & 32 & $32 \%$ \\
$>3$ million & 8 & $8 \%$ \\
\hline & $\mathbf{1 0 0}$ & $\mathbf{1 0 0 \%}$ \\
\hline
\end{tabular}

Source: Summary of Results and Data Processing

As for revenues, based on the results of this research is that $68 \%$ of respondents who are actively engaged as a member of the empowerment of micro businesses, while the remaining status as a housewife, Assistant household and farm workers. The respondent's status as micro businesses engaged in the trade with the micro-scale, such as food vendors, toys, clothing and so forth, but it is also engaged in services, such as services of make-up, services of a therapist, sewing services and other so. Of the respondents who have a job or perform micro, then the average income earned is $27 \%$ with an average income of about $\mathrm{Rp} 500,000$, - to. Rp 1.000 .000 , -; 49\% with an average income of $\mathrm{Rp} 1,000,000$, to $\mathrm{Rp}$ $2,000,000$. 
Table 3 Respondents based on Types of Employment

\begin{tabular}{|c|c|c|c|}
\hline No. & Employment Type & $\begin{array}{c}\text { Frequency } \\
\text { (person) }\end{array}$ & $\begin{array}{c}\text { Percentage } \\
(\%)\end{array}$ \\
\hline 1 & $\begin{array}{l}\text { Enterprises products and food } \\
\text { - } \quad \text { Seller of cosmetics, accessories, } \\
\text { jackets, sandals, credit items and others } \\
\text { - Seller child snacks, snacks, } \\
\text { meatballs, fried foods, whole milk, } \\
\text { vegetable rice cake, chips, etc. }\end{array}$ & 46 & $46 \%$ \\
\hline 2 & business services & 32 & $32 \%$ \\
\hline \multirow{5}{*}{3} & $\begin{array}{l}\text { - } \text { Teacher } \\
\text { - ART, farm labourers, catering, } \\
\text { acupuncture therapist, boutique, } \\
\text { wedding organizer, tailors, production of } \\
\text { shoes and bags, garment, laundry, etc. }\end{array}$ & & \\
\hline & More & 22 & $22 \%$ \\
\hline & Housewife & & \\
\hline & Bird breeders, farmers & & \\
\hline & Total & 100 people & $100 \%$ \\
\hline
\end{tabular}

Creating employment, almost $68 \%$ of respondents noted that after obtaining Islamic micro financing, they can run the business independently. Of the total who run micro-enterprises, then the $50 \%$ run the business with her husband and $18 \%$ doing business with family members. Thus, Microfinance creates jobs not only in the micro-finance borrowers, but for other family members. Although, creating employment in new micro businesses is still limited on their own families.

\subsection{Achievement maqashid Al-Sharia}

Achievement maqashid Al-Sharia in KOPMU-DT member empowerment refers to the proposed As-Syatibi (Dusuki \& Bouheraoua, 2011) and technically based on what has been developed by Alam et.all (2015) in measuring the performance of Islamic Microfinance by maqashid Al-Sharia. Based on the research results, it can be seen maqashid Al-Sharia achievement that the member KOPMU-DT.

1) Religion (Ad-Din), changes in religious practice. Among the respondents agreed that Islamic microfinance programs have positive impact on the practice of religiosity better. Religiosity in this study measured using three indicators, namely indicators of appreciation or the Islamic faith, worship or implementation of sharia and practice or morals. All three indicators are broken down into 25 grains of questions used as a measure of the level of religiosity in KOPMU-DT.

Appreciation or the Islamic faith indicated by how often respondents remember and associate everything that happened in his life that everything 
happens by the will of Allah. Worship or implementing Sharia intensity indicated by how often and how much the quality of the respondents in performing activities of daily worship either mandatory or sunnah, while practice or morals is indicated by how often the implementation of additional practice daily as the implications on the Islamic faith and confidence in the implementation of worships.

Indicators of appreciation or Islamic aqeedah on members of KOPMUDT are in the range of medium categories. The indicator of worship or the implementation of Sharia in-DT KOPMU members belong to the higher category. Indicators of worship include the intensity and quality of ritual worship both mandatory or Sunnah. The form of implementation includes several things, including the accuracy of the implementation of fardhu prayer and improving quality by carrying out it in congregation and coupled with the intensity of the implementation of the Sunnah prayer.

In addition, there are also exercising their mandatory or sunnah fasting, generous attitude towards each other, together with the intensity and quality of the Qur'an, the intensity and quality pray, obedience to avoid usury, and that made the difference for a Muslim woman is obedience in maintaining veil. Based on the findings from the field, most of the members have to follow-DT KOPMU membership in more than three years. It has affected the pattern and quality of worship of members. Habituation Koran every weekend accompanied by guidance counsellor's material by any court to be one of the medias for members to have an opportunity to learn Islam better. From interviews with members, implied the more prominent is the intensity and quality of togetherness with the Koran and the habituation to giving charity for others. Several members mentioned that earlier they were not able to read the Qur'an, but with the weekly council meetings makes the members more determined to learn the Koran.

Other than that, practice indicator values or morals in-DT KOPMU members belong to the higher category. Indicators practice or this character including the implementation belief in Allah and worship rituals are applied in everyday life or in other words, a person's attitude on good terms with each other. This can be reflected in their attitude, generous and help each other to others, honest and fair in the act.

2) Life (An-nafs) changes in family living standards. Almost all respondents agreed that participation in Islamic Microfinance programs have a positive impact on their lives. Everyone said that their condition of life has significantly better after being involved in Islamic Microfinance program, as well as their health status. Nearly $90 \%$ of respondents believed that microfinancing that they receive to add the cost of health control them effectively. Everything stated that his health condition is now better than ever. Although, most among respondents stated that their health condition could not be as good as before due to aging.

Change in social participation. Almost all respondents agreed that their increased social participation after being involved in Islamic Microfinance program. The majority of respondents have a good relationship with the brothers and participates in various community activities. They are present in mentoring activities on a regular basis to discuss issues that are run at the same business together - the same study the science of religion. Through this program, the housewives are becoming more open to the public in the surrounding 
environment, sharing affection and motivate each other to change a better life. At any given times a companion or caretaker of the empowerment group provides training skills for mothers, such as making cakes, cooking, sewing, making skills and others to inspire women in running businesses that can provide additional income. So, overall Islamic micro finance could increase the positive social activities to its members.

3) Property (Al-Aql) Changes in education level. Nearly $70 \%$ of respondents agreed that participation in Islamic Microfinance could increase knowledge. They acquire various types of knowledge they gained from a variety of economic activities through credit. Although $30 \%$ of respondents said that they did not acquire new knowledge of their activities. Change in skills and business experience. Nearly $60 \%$ of respondents agreed that their involvement in the financing of Islamic micro positive impact on the business skills and experience. Among them, $20 \%$ experienced a positive change is very high. Although, 20\% found and skills and business experience they are not effective because the majority of their status as a housewife. Besides that, assessment standards in this indicator based on the growing number of courses / trainings attended, the higher the ratings given. Results of field interviews, the average respondent had difficulty of access and the ability to get the course / training. Although course / training has started being implemented by the driver of the PKK in the village / village or other institutions, in general they are less motivated to attend the training.

Changes in knowledge about family, almost all respondents agreed that the involvement of Islamic micro finance programs positing impact on the knowledge of their families. Among them, 30 per cent showed a positive change in this aspect. Many respondents who ultimately have the ability to deliver their children obtain a higher education. This indicator has indicated the respondent's role as wife and mother of his children to be Madrasatul ula, the first educators for their families. This function is implemented on the involvement of the respondent to accompany their children to study, do homework from school, accompanying the children studied religion, a reminder of the family in performing worship.

4) Lineage / honoraria (Al-Nasb) lineage changes / honor among family members. Almost all respondents agreed that their involvement in the microcredit program to change the lineage among family members. Among these respondents, 40 percent showed a very positive change. Change public perception. About 80 percent of respondents agree that public perceptions with respect to their family increased positive for their involvement in the microcredit program. The majority of respondents stated that they received the award, which increased from society after their living conditions improved. However, 20 percent of respondents reported no change in perception

5) Wealth (Al-Mal) Changes in monthly household income. Almost all respondents agreed that their household income had increased as a result of their involvement in a microfinance program (Table 4). These findings also indicate that they are judiciously utilizing micro finance their economic activities. Change in asset ownership. Almost all respondents agreed that they acquire some assets from their business income with using micro-finance wisely for economic activities. They managed to buy some assets for themselves apart from capital expenditure on work, family and credit payments (Table 4). About 
$50 \%$ of respondents reported a very positive effect on asset ownership because they have significant assets. For example,

Table 4 Achievement of Micro Financing Program Based Maqashid Al Shariah

\begin{tabular}{|c|c|c|c|c|c|c|}
\hline \multirow[t]{2}{*}{ Principle } & \multirow[t]{2}{*}{ variable Measurement } & \multirow{2}{*}{\multicolumn{5}{|c|}{ Scale Data $(\%)$}} \\
\hline & & 1 & & & & 5 \\
\hline \multirow[t]{3}{*}{ Religion (Ad-Deen) } & Changes in creed of Islam & & 10 & 20 & 40 & 30 \\
\hline & Changes in worship practices & - & 5 & 10 & 40 & 45 \\
\hline & Changes in morals & - & - & 20 & 30 & 50 \\
\hline \multirow[t]{2}{*}{ Soul (an-nafs) } & Changes in family living standards & - & - & 10 & 60 & 30 \\
\hline & Changes in social participation & - & - & 20 & 65 & 15 \\
\hline \multirow[t]{3}{*}{ Intellectual $(A l-A q l)$} & Changes in the level of knowledge & - & - & 30 & 70 & \\
\hline & Changes in skills and business experience & - & & 40 & 60 & \\
\hline & Changes in knowledge about family & - & 10 & 20 & 40 & 30 \\
\hline \multirow[t]{2}{*}{$\begin{array}{l}\text { Descendants }(A n- \\
\text { Nashl) }\end{array}$} & $\begin{array}{l}\text { Changes lineage / honour among } \\
\text { family members }\end{array}$ & - & - & 10 & 50 & 40 \\
\hline & Change public perception & - & - & 20 & 50 & 30 \\
\hline \multirow[t]{2}{*}{ Wealth (Al-Maal) } & Changes in the family's monthly income & - & - & 10 & 70 & 20 \\
\hline & Changes in ownership asset & - & - & 25 & 60 & 15 \\
\hline
\end{tabular}

\section{Information:}

$1=$ very negative; $2=$ negative; $3=$ No change; $4=$ Positive and $5=$ very positive

\section{CONCLUSION AND RECOMMENDATION}

All this time, the measurement of Islamic Microfinance performance similar with the other microfinance measurement in general. Though the concept of tauhid as epistemology should be the main feature of Islamic Microfinance, not only the base funding that should be free of usury, but all aspects of the implementation of Islamic Microfinance program that should lead to the achievement of the objectives maqashid Al-Sharia. Based on the results of the study, mothers who become agents of empowerment of poor families have actively pursued the development programs run by KOPMU-DT. They have a strong attachment to KOPMU-DT, because mentoring is done intensively per week to members of the empowerment of institutions.

The collected data were analyzed based on the achievement of the five principles in Maqasid Al-Shariah. Almost all of the principles increased significantly after participating in Islamic Microfinance program. However, in between these five principles, indicators Ad-Din, al-nafs al-Nasb and Al-Mal most improved sigifikan after participating in Islamic Microfinance program. However, Al-Aql indicator is not significantly enhanced by this program in comparison with the other principles. They assume that their involvement in Islamic Microfinance programs are not much help them gain additional knowledge or business skills. This is understandable, because it is based on field studies KOPMU companion-DT does not give much general knowledge and business skills, because that is the focus of the program is how the members of the poor families assisted in financing that will support the family finances and provide spiritual guidance to strengthen faith. Another factor is due to the limited time of the mentoring program is done. This is due to the limited number of escort while the number of auxiliaries that should be visited numerous and widespread in the area - a suburb of Bandung highway. 
Based on the results of the study, household income on average increased after following the Islamic Microfinance program, but the increase in this revenue has not significantly increase the assets owned by the family involved in Islamic Microfinance program. This is because the micro-financing provided by KOMU-DT is still very limited in number, so that only a relatively small capital increase for members. In addition, increasing the amount of financing for members who successfully returns smoothly financing tends to be slow. The main factor of the cause is due to the limited capital owned by KOPMU-DT that amount should be divided equally among the members in all regions of the auxiliaries.

Forward, to improve the performance of Islamic Microfinance, especially in KOPMU-DT, business mentoring needs to be improved in running the business, the members of empowerment to successfully run the business and restore discipline in financing, should be enhanced appreciation of the continued number of financing in cooperation with the Islamic banking institutions. In addition, for business mentoring can make cooperation with the association of Muslim entrepreneurs who have been successful. Thus, we can boost the entrepreneurial skills of the members in the operations. Without having to leave the main principles of empowerment, namely by taking into account the main principles in maqashid Al-Sharia.

\section{References}

Abdullah, R., \& Ismail, A.G (2014). Al-Tawhid in Relation to The Economic Order of Microfinance Institutions. Humanomics, 30(4), 325-348.

Ahmed, H. (2002). Financing micro enterprises: an analytical study of Islamic microfinance institutions. Journal of Islamic Economic Studies, 9(2)

Alam, M. M., Hassan, S., \& Said, J. (2015). Performance of Islamic Microcredit in Perspective of Maqasid Al-Shariah. Humanomics, 31 (4), 374-384.

Ali, A. H., Abu-Hadi, A.O., \& Ali, A. Y. (2013). The Accessability of Microfinance for Small Businesses in Mogadishu, Somalia. International Journal of Humanities and Social Science, 3(11), 172-180.

Aslaam, N. M. (2014). Role of Islamic Microfinance in Poverty Alleviation in Pakistan: An Empirical Approach. International Journal of Academic Research in Accounting, Finance and Management Sciences, 4(4), 143152.

BPS. (2018). Poverty and Inequality. Retrieved from the Central Bureau of Statistics: https://www.bps.go.id/subject/23/kemiskinan-danketimpangan.html

Choudhury, M. A. (2010). On the theme of Tawhid, Zakah and Waqf in a metaepistemological general-system model. Seventh International Conference: The Tawhidy Epistemology: Zakat and Waqf Economy, National University of Malaysia, Selangor, 6- 7 January.

Choudhury, M. A. (2011). Islamic Economics and Finance: An epistemological Inquiry. Emerald Group Publishing. 
Dar, H. A. (2004). Demand for Islamic financial services in the UK: chasing a mirage. Economics Research Paper No. 4-11, Loughborough University, available at: https://dspace.lboro.ac. uk / 2134/335

Durrani, M. K., Usman A. Malik, M. I., \& Ahmad, S. (2011). Role of Micro Finance in Reducing Poverty: A Look at Social and Economic Factors. International Journal of Business and Social Science, 2(21), 138-144.

Dusuki, A., \& Bouheraoua ,S. (2011). The Framework of Maqasid Al-Shariah (Objectives of the Shariah) and Its Implications for Islamic Finance. ISRA Research Paper No: 22.

Fauzia, I. J. (2016). Urgency of Implementation of Green Economy Perspective Approach Dharuriyah In maqashid Al-Shariah. Journal of Economics and Business Islam, 2(1).

Karim, N., Tarazi, M., \& Reille, X. (2008). Islamic Microfinance: An Emerging Market Niche. CGAP. Washington, DC.

Knight, T., \& Farhad, H. (2008). Helping the Needy, Factors Influencing the Development of Microfinance in Barbados. Brooks World Poverty Institute, 1-17.

Komi, M., \& Croson, R. (2005). Experiments in Islamic Microfinance. Dallas, TX: University of Texas.

Kumar, M., Bohra, N., \& Johari, A. (2010). Micro-finance as an Anti-poverty Vaccine for Rural India. International Review of Business and Finance, 29-35.

Mikkelsen, B.H., Olander, K., Gubay, M. T., \& Mekonnen, W. (2008). The Swedish Civil Society Organizations / Non-governmental Organization Cooperation Program, SIDA Evaluation, Stockholm, available at: www.sida.se/publications.

Mizanur, R, M. (2010). Islamic Microfinance Program And Its Impact On Rural Poverty Alleviation: The International Journal of Banking and Finance, 7(1), 119-138.

Morsid, N. (2014). The Effectiveness of Islamic Microfinance in Brunei Darussalam: A Case Study. The Journal of Muamalat and Islamic Finance Research, 11(1), 33-58.

Mursal. (2016). Development of Islamic Microfinance Institutions in West Sumatra Based Local Wisdom "Tigo Sajarangan Furnace". Analytica Islamica, 5(1), 108-124.

Nurasyiah, A., Aprilliani, S. U., Mahri, A. J. W., \& Firmansyah. (2016). The Challenges of Human Capital Performance in Developing Baitul Maal Wat Tamwil in Indonesia. The UPI 1st Global Conference on Business, Management and Entreupreuneurship- Atlantis Press: Thompson Reuteurs. 
Oluyombo, O. O. (2012). The Place of Cooperatives in Nigerian Microfinance. Cooperative Finance in Developing Economies. Logos: Soma Prints Limited, 81-95.

Financial Fervices Authority. (2018). Islamic Banking Statistics - January 2018. Retrieved from the Financial Services Authority: https://www.ojk.go.id/id/kanal/syariah/data-dan-statistik/statistikperbankan-syariah/Pages/Statistik-Perbankan-Syariah-Januari-2018.aspx

Rahman, R. A., \& Dean, F. (2013). Challenges and solutions in Islamic microfinance. Humanomics, 29(4), 293-306.

Rena, R., \& Tesfy, G. (2006). Poverty and Microfinance in Eritrea - A Discourse. The Global Journal of Finance and Economics, 4 (2), 147-161.

Sekaran, U., \& Bougie, R. (2013). Research Methods for Business A SkillBuilding Approach Six Edition. United Kingdom: John Wiley \& Sons Ltd.

Shastri, R. (2009). Micro-finance and Poverty Reduction in India (A Comparative Study with Asian Countries). African Journal of Business Management, 136-140.

Shinkafi, A. A., \& Ali, N. A. (2017). Contemporary Islamic Shari'ah Maqasid on economic studies: a systematic literature review. Humanomics, 33(3).

Usman, A. S., \& Tasminn, R. (2016). The Role of Micro-finance Islamicc in Enhancing Human Development in Muslim Countries. Journal of Islamic Finance, 5(1), 53-62. 